\title{
The Effect of Sodium Chloride and Magnesium Chloride Salts on Perlite Aggregate Lightweight Concrete
}

\author{
[Mahyar SHOAEI, Rüstem GÜL and Türkay KOTAN]
}

\begin{abstract}
In this study, the effect of $\mathrm{NaCl}$ and $\mathrm{MgCl}_{2}$ salts in lightweight concrete (LWC) with raw perlite aggregate was investigated. For this purpose, 360 concrete samples with $\emptyset 100 / 200 \mathrm{~mm}$ cylindrical shape were produced. In concrete mixture, the Micro Silica Fume (SF) and Fly Ash (FA) were replaced with cement at the rate of $10 \%$ and $20 \%$ of its weight, respectively. The produced concrete samples before were waited in standard water curing for 28 days and then they were subjected to Sodium Chloride and Magnesium Chloride solutions at the rate of $3.5 \%$ and $5.0 \%$ further in mixtures of these at the rate of $1.75 \%+1.75 \%$ for $28,90,56$ days. Besides, the standard water curing was applied to samples. The compressive strength, unit weight and water absorption standard tests were made on three samples for each condition and average results obtained from tests were given in this paper.

The results showed that; the effect of $\mathrm{MgCl}_{2}$ solutions on samples with additives of $10 \% \mathrm{SF}$ and $20 \%$ FA was fewer compared to standard samples. Besides, $\mathrm{NaCl}$ solution and the mixture of these two salts had little effect on LWC. On the other hand, the more $\mathrm{MgCl}_{2}$ solution penetrated into the concrete; because of the specimens with $20 \%$ FA can absorb more water. As a result, in $\mathrm{MgCl}_{2}$ solution for 90 days, the standard samples were most affected; meanwhile the samples with $20 \%$ FA and the samples with \% $10 \mathrm{SF}$ were affected the least, respectively.
\end{abstract}

Keywords - lightweight concrete, perlite, micro silica fume, fly ash, sodium chloride, magnesium chloride

\section{Introduction}

It is known that about $85-90 \%$ of produced buildings in worldwide is realized as reinforced concrete structural system. In this case; information about reinforced concrete (RC) and concrete materials has gained importance a lot. This information is primarily for aggregates, binders and admixtures. But also, those are for production, casting and protection conditions of concrete based on durability. In the recent years; many advances have arisen in the areas of concrete production and using. In Turkey located on earthquake zones, the concrete quality and correspondingly strength and durability of RC systems are so important. [1].

Mahyar SHOAEI and Rüstem GÜL

Engineering Faculty / Atatürk University

Turkey

Türkay KOTAN

Engineering and Architecture Faculty / Erzurum Technical University Turkey
Concretes of marine structures such as harbors and piers can be damaged by the seawater and affected adversely. Sometimes to take measures against it; the existent mineral admixtures are used. Examples of these materials are blast furnace slag, silica fume, fly ash and other natural pozzolans.

Concrete and reinforced concrete structures are under the influence of salts which is found in their environment and atmosphere. In case of not taking some necessary measures in the concretes happening structures; the structure has been damaged in a very short period of time and cannot realize its function. Although chlorides are not as dangerous as sulfates, in some cases of various types can have some dangerous effects on concrete and reinforced concrete structures. Calcium chlorides, potassium chloride (KCI), magnesium chloride $\left(\mathrm{MgCl}_{2}\right)$ are chlorides damaging in concrete [2].

In this study; examined salts $\left(\mathrm{MgCl}_{2}, \mathrm{NaCl}\right)$ are mostly found in sea water environment. Majority of structures which expose to the sea water carries the salt on the agenda in terms of effects in the structures and some studies have been realized and will be realized to decrease the effects.

All measures (w/c rate is low (w/c $\leq 0.45)$, decreasing the effects of salts ( $\mathrm{NaCl}, \mathrm{MgCl}_{2}$, Sulfate etc.) are valid measures so as to paint the upper surface of concretes (using pozzolanic substance) and to reduce the effect of sea water. Generally; the salinity of the seas and oceans is $36-39 \mathrm{~g} / \mathrm{l}$. So, in this thesis in the light of literature; $\mathrm{MgCl}_{2}$ and $\mathrm{NaCl}$ solution were produced in the rates of $3.5 \%, 5 \%$ and $1.75 \% \mathrm{MgCl}_{2}+1.75 \% \mathrm{NaCl}$.

\section{Material and Method}

\section{A. Material}

As binding material in perlite aggregate concrete produced for experiments; Portland cement (PÇ 42.5) produced by Asskale Cement Plant in 2012 and the drinking water of Erzurum city were used. Perlite is a naturally occurring siliceous volcanic rock. In this study, Erzincan Mollaköy raw perlite aggregate for $100 \%$ of the tests were used. Perlite aggregates were sieved in the range of $0-8 \mathrm{~mm}$. Aggregates was separated by $0-2,2-4$ and $4-8 \mathrm{~mm}$ sieve and cumulative passing \% values for 2,4 and $8 \mathrm{~mm}$ square sieve were 40,61 and $100 \%$, respectively.

Chemical and physical properties of the perlite aggregate were given in Table 1. 
Proc. of The Fourth Intl. Conf. On Advances in Civil and Structural Engineering - CSE 2015

Copyright (C) Institute of Research Engineers and Doctors, USA .All rights reserved.

ISBN: 978-1-63248-070-5 doi: 10.15224/ 978-1-63248-070-5-41

Table 1. Chemical and Physical properties of Perlite $[3,4]$

\begin{tabular}{|c|c|c|c|}
\hline \multicolumn{2}{|c|}{ Chemical Properties } & \multicolumn{2}{|c|}{ Physical Properties } \\
\hline Component & $(\%)$ & Properties & Value \\
\hline $\mathrm{SiO}_{2}$ & $71-75$ & Specific gravity $\left(\mathrm{g} / \mathrm{cm}^{3}\right)$ & 1.999 \\
\hline $\mathrm{Al}_{2} \mathrm{O}_{3}$ & $12.5-16$ & Density $\left(\mathrm{g} / \mathrm{cm}^{3}\right)$ & $2.2-2.4$ \\
\hline $\mathrm{Fe}_{2} \mathrm{O}_{3}$ & $0.3-0.50$ & Water absorption $(\%)$ & 4.6 \\
\hline $\mathrm{CaO}$ & $0.4-0.82$ & Loose unit weight & 1116 \\
\hline $\mathrm{MgO}$ & $0.02-0.03$ & $\left(\mathrm{~kg} / \mathrm{m}^{3}\right)$ & \\
\hline $\mathrm{SO}_{3}$ & $0-0.2$ & Tight unit weight & 1225 \\
\hline Ignition Loss & 2.5 & $\left(\mathrm{~kg} / \mathrm{m}^{3}\right)$ & \\
\hline $\mathrm{Na}_{2} \mathrm{O}$ & 3.2 & Water absorption for 30 & 2.43 \\
\hline $\mathrm{K}_{2} \mathrm{O}$ & $4-5$ & minutes $(\%)$ & \\
\hline Free $\mathrm{CaO}$ & - & & \\
\hline $\mathrm{H}_{2} \mathrm{O}$ & $2-6$ & & \\
\hline
\end{tabular}

In this study; super plasticizer additive Glenium C303 which has capable of high-range water reducer as $1.5 \%$ of the cement was used.

The silica fume is gained during the production with melting method of silica or silicon-iron alloy. Although silica fume is a waste material; it entered both to a position of byproduct material and it became the most valuable materials among other pozzolanic materials because silica fume has high pozzolanic activity.

Behavior of silica fume in concrete is physicochemical. Physical part of this behavior is reducing the size of the space system in the cement paste matrix, in particular in the aggregate-cement interface [5]. Silica Fume chemical composition was given in Table 2. The unit weight of silica fume is $245 \mathrm{~kg} / \mathrm{m}^{3}$.

It is a valuable concrete additive having pozzolanic concrete with Fly Ash and affecting positively a lot of features of the concrete. Because of the global nature of FA; it improves the workability of concrete. In this thesis study; Fly Ash which was taken from Orhaneli Thermic Power Plant in Bursa was used. The physical, chemical and mechanical properties of Fly Ash were given in Table 2.

Table 2. The chemical and physical properties of SF and FA [6]

\begin{tabular}{lcc}
\hline Component / Properties & Silica Fume (\%) & Fly Ash (\%) \\
\hline $\mathrm{SiO}_{2}$ & 94.6 & 42.14 \\
$\mathrm{Al}_{2} \mathrm{O}_{3}$ & 1 & 19.38 \\
$\mathrm{Fe}_{2} \mathrm{O}_{3}$ & 0.50 & 4.64 \\
$\mathrm{CaO}$ & 1.40 & 26.96 \\
$\mathrm{SO}_{3}$ & 0.21 & 2.43 \\
$\mathrm{Specific}$ gravity $\left(\mathrm{g} / \mathrm{cm}^{3}\right)$ & 2.36 & 2.18 \\
Specific surface $\left(\mathrm{cm}^{2} / \mathrm{g}\right)$ & 200000 & - \\
Insoluble residue & 2.16 & - \\
Ignition loss & - & 1.34 \\
$\mathrm{Free} \mathrm{CaO}$ & - & 4.34 \\
$\mathrm{MgO}$ & - & 1.78 \\
$\mathrm{~K}$ & - & 1.13 \\
\hline
\end{tabular}

\section{B. Method}

In this study, the raw perlite obtained from Erzincan Mollaköy in Turkey was used as aggregate. The percentage of fine aggregate should be among $40 \%$ and $60 \%$ for an aggregate which has the smallest grain size $8 \mathrm{~mm}$ in practice according to dry loose volume basis. With this arrangement, the ratio of the units of class respectively were determined as $40 \%$ 0-2 mm, 21\% 2-4 mm, 39\% 4-8 mm.

Additionally; in LWC mixtures, Silica Fume and Fly Ash were used instead of some amount of cement weight for strong cement matrix. The objective of these pozzolanic materials using is to increase the ultimate strength and workability.

The cement dosage is $350 \mathrm{~kg} / \mathrm{m}^{3}$ and $\mathrm{w} / \mathrm{c}$ rate is 0.35 . Also, the amount of $10 \%$ SF and $20 \%$ FA additives was determined according to cement weight in mixtures. The plasticizer admixture was used as $1.5 \%$ of the cement weight.

The unit weight of hardened concrete was determined according to ASTM C 567. For the compressive strength of samples, standard experiment method is provided in TS 500, TS 3114 ISO 4012, ASTM C 31 and ASTM C 39. At the end of 28,56 and 90 day procedures, the cylinder cappers were made to samples for a uniform load distribution and those were broken under the pressure load with test press.

For the capillary water absorption test; the samples were dried at $105 \pm 5^{\circ} \mathrm{C}$ oven for $24 \mathrm{~h}$ and then their bottom faces were touched to water in the manner of entered to water 0.5 $\mathrm{cm}$. The samples were removed from water after $24 \mathrm{~h}$, they were weighted with scale have $1 \mathrm{~g}$ precision and the amount of water absorbed by samples via capillarity was determined.

Also, for the volumetric water absorption; the samples weighed in dry state were put into the curing pool for $24 \mathrm{~h}$ and later they were weighed in state of saturated dry-surface.

\section{Result and Discussion}

In this chapter; results obtained from aggregate and concrete experiments are shown as Tables and Figures.

The grading of perlite aggregate, i.e. percentage values of passing the sieve for $8,4,2 \mathrm{~mm}$ and pot sieves were determined as $100,61,40$ and $0 \%$, respectively. It was realized that this grading is accord with reference grading for the maximum grain size of $8 \mathrm{~mm}$ in TS 802 .

Unit densities of mineral-based aggregates do not excess $2000 \mathrm{~kg} / \mathrm{m}^{3}$ or loose mass densities of some aggregates do not excess $1200 \mathrm{~kg} / \mathrm{m}^{3}$ are to be identified as light aggregates [7]. The dry unit weights of perlite aggregate for different grain class ranged from $1129-1154 \mathrm{~kg} / \mathrm{m}^{3}$. The wet unit weights of produced fresh concrete samples were determined and were showed in Table 3.

Table 3. The unit weight of fresh concrete

\begin{tabular}{lc}
\hline Mixture Type & Unit Weight $\left(\mathbf{k g} / \mathbf{m}^{\mathbf{3}}\right)$ \\
\hline Light concrete with 10\% Silica Fume & 1.910 \\
Light concrete with 20\% Fly Ash & 1.900 \\
Light concrete without Mineral Additive & 1.885 \\
\hline
\end{tabular}




\section{A. Compressive Strength}

The $\mathrm{NaCl}$ and $\mathrm{MgCl}_{2}$ salts were solved in water with three ratios $(3 \%, 5 \%$, mix $1.75 \%+1.75 \%)$ and the samples were waited in this solutions for 28, 56, 90 days. Also; the normal samples without mineral additive (0\% MA) and samples with mineral additive (10\% SF and 20\% FA) were left to standard water curing and the experiments were performed on the samples that removed from water at the end of 28,56 and 90 days. The experimental results such as compressive strength, unit weight and water absorption were graphically presented here.

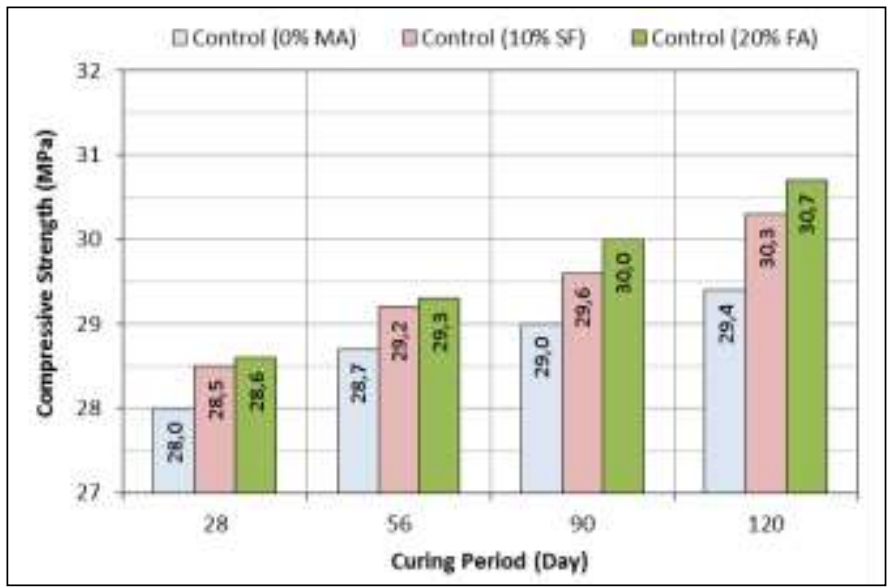

Figure 1. Compressive strength for standard curing

When the compressive strengths for 28 day in Figure 1 was investigated; concrete samples with $20 \%$ FA showed the highest strength. The compressive strength of samples with $10 \% \mathrm{SF}$ and without additive followed this, respectively. An increasing was observed in strengths of samples with $20 \%$ FA and $10 \%$ SF because the strength of concrete samples under normal curing conditions increase normally day by day.

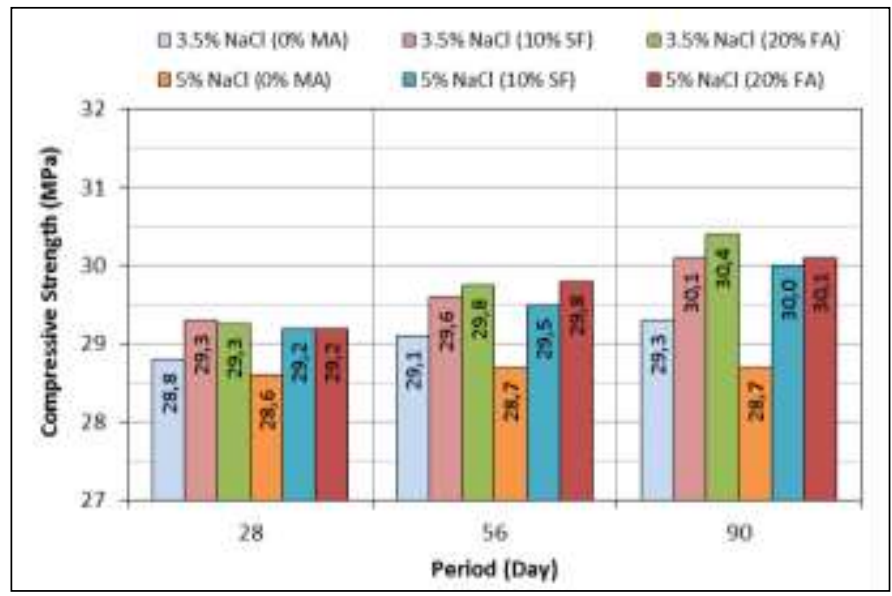

Figure 2. The compressive strength of concrete samples subjected to $3.5 \%$ and $5 \% \mathrm{NaCl}$ solutions

The compressive strength test results of concrete samples exposed to $3.5 \%$ and $5 \% \mathrm{NaCl}$ solutions were graphically shown in Figure 2 for 28, 56 and 90 day. When the compressive strengths for 28 days were investigated in Figure 3; concrete samples with $10 \%$ SF gave the highest strength for $3.5 \% \mathrm{NaCl}$ solution.
The results showed that; the effects of $\mathrm{NaCl}$ solution on concrete samples are so low or sometimes there are no effects of $\mathrm{NaCl}$. However; day by day, more $\mathrm{NaCl}$ enters into the concrete and this case causes a lot of spaces in concretes.

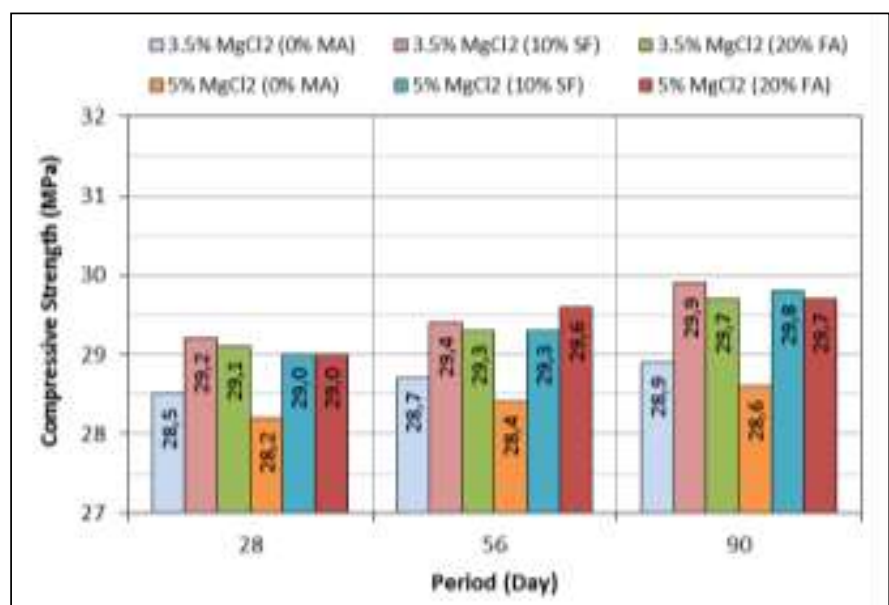

Figure 3. The compressive strength of concrete samples subjected to $3.5 \%$ and $5 \% \mathrm{MgCl}_{2}$ solutions

The compressive strength test results of concrete specimens which are exposed to $3.5 \%$ and $5 \%$ magnesium chloride solutions were graphically shown in Figure 3 for 28th, 56th and 90th days. When the compressive strengths for 28 days were investigated in Figure 4; concrete samples with $10 \%$ SF gave higher strength than FA samples for 3.5\% $\mathrm{MgCl}_{2}$ solution.

Briefly; $10 \%$ SF samples were less affected from magnesium chloride solution than FA and witness samples. Also, it was determined that the effect of magnesium chloride is harmful on the concrete surfaces.

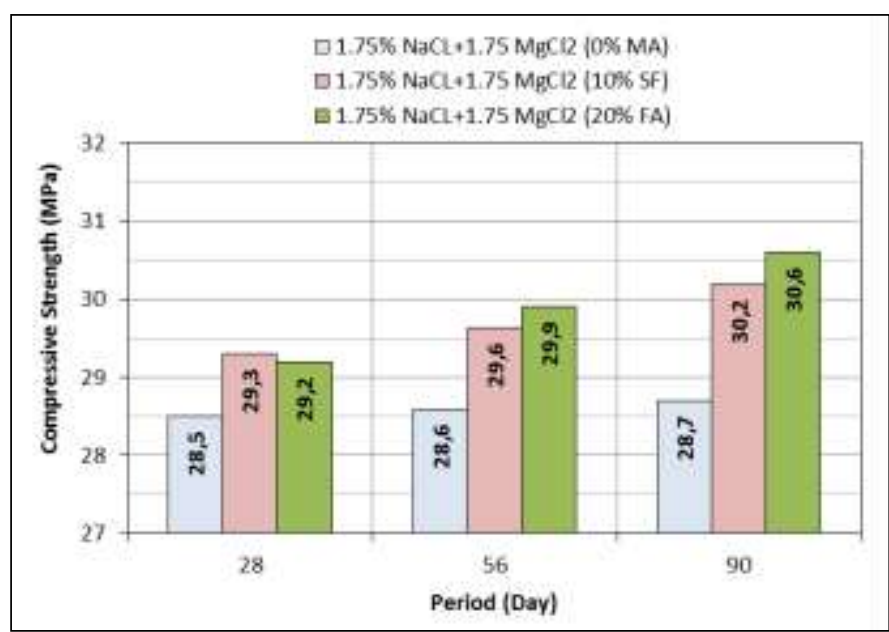

Figure 4. The compressive strength of concrete samples subjected to $1.75 \%$ $\mathrm{MgCl}_{2}$ and $1.75 \% \mathrm{NaCl}$

When the compressive strengths for 28 days were investigated in Figure 4; concrete samples with $10 \%$ silica fume gave the highest strength but $20 \%$ FA samples gave higher strength in 56th and 90th days and the reason of this case is that it used more filler (20\% FA) silica fume. Additionally; $1.75 \%$ magnesium chloride and $1.75 \%$ sodium chloride solutions had less effect over the concrete surfaces. 
Proc. of The Fourth Intl. Conf. On Advances in Civil and Structural Engineering - CSE 2015

Copyright $(\odot$ Institute of Research Engineers and Doctors, USA .All rights reserved.

ISBN: 978-1-63248-070-5 doi: 10.15224/ 978-1-63248-070-5-41

\section{B. Unit weight (UW)}

The dry unit weights of concrete samples were also measured for standard curing and effect of salt solutions. According to obtained results; in the standard curing, the unit weights of samples increase day by day. It was seen that the UW increased more in samples with $10 \%$ SF, $20 \%$ FA and in standard curing. The UW values of samples without mineral additive in solutions of $3.5 \% \mathrm{NaCl}, 5 \% \mathrm{NaCl}$ and in mixture $\left(1.75 \% \mathrm{MgCl}_{2}+1.75 \% \mathrm{NaCl}\right)$ dropped very few.

In $3.5 \%, 5 \% \mathrm{MgCl}_{2}$ solutions; UW of samples without mineral additives are so less than $\mathrm{NaCl}$ and as the curing time increases; UW increasing decreases. In samples of $10 \% \mathrm{SF}$ and $20 \% \mathrm{FA}, 3.5 \%, 5 \% \mathrm{NaCl}$ and mixture $\left(1.75 \% \mathrm{MgCl}_{2}+\right.$ $1.75 \% \mathrm{NaCl}$ ) solutions seem that they have no effects. Unit weights of samples of $10 \% \mathrm{SF}$ and $20 \% \mathrm{FA}$ are less than samples without additives in $3.5 \%$ and $5 \% \mathrm{MgCl}_{2}$ solutions.

\section{Capillary ( $C$-WA) and volumetric water absorption ( $V$-WA}

In study finally, the capillary and volumetric water absorption amounts of the concrete samples for standard water curing and different salty solution conditions were determined, separately. The obtained results by using the methods described in Section 2 were given graphically in the following.

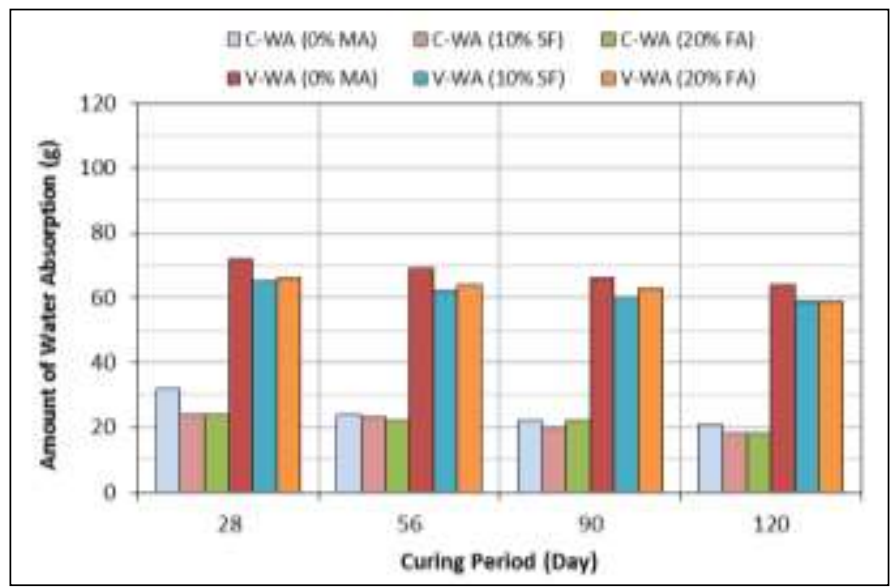

Figure 10. Water absorption amount of samples kept in standard water

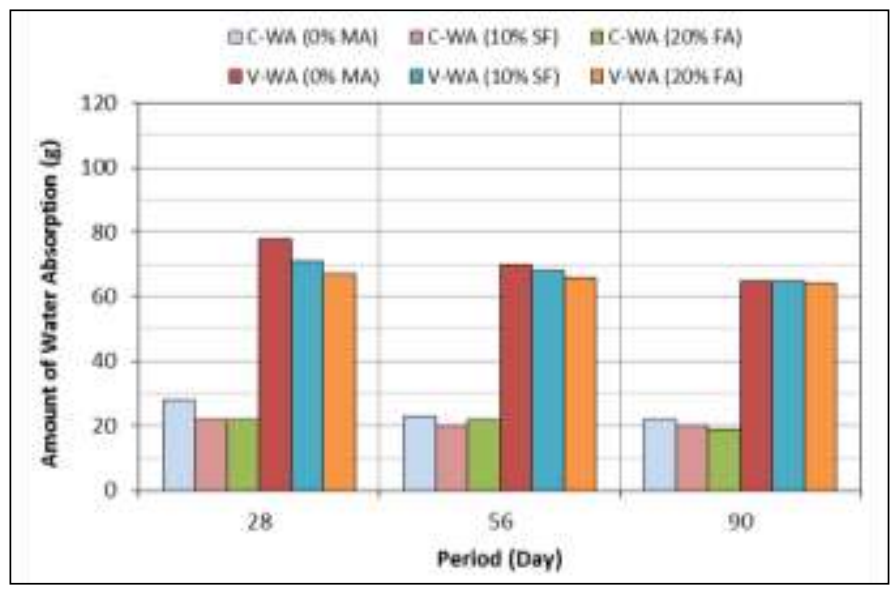

Figure 11. Water absorption amount of samples kept in $3.5 \% \mathrm{NaCl}$ solution

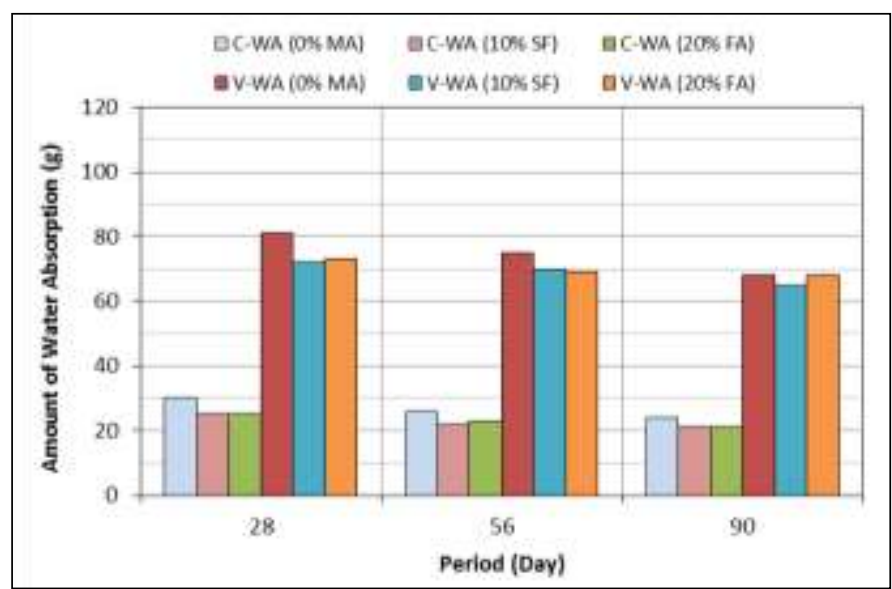

Figure 12. Water absorption amount of samples kept in $5 \% \mathrm{NaCl}$ solution

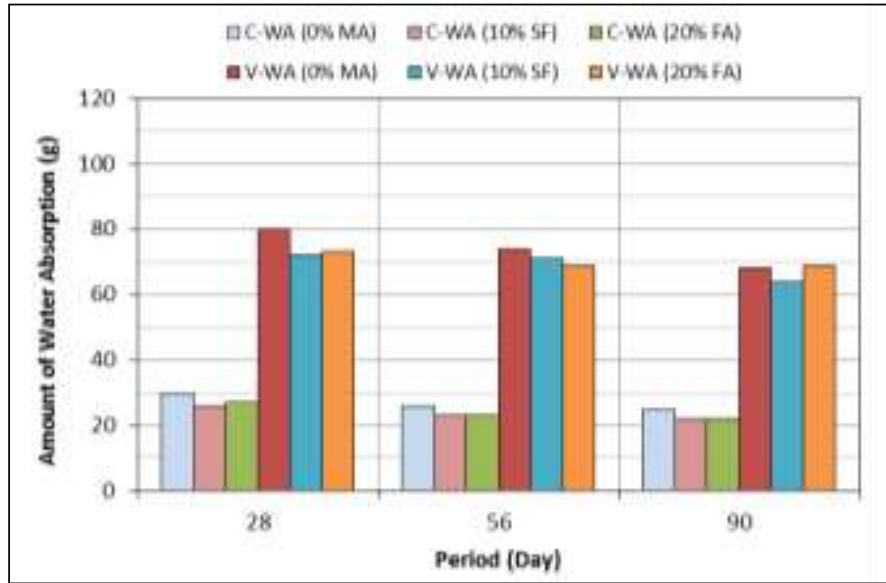

Figure 13. Water absorption amount of samples kept in $3.5 \% \mathrm{MgCl}_{2}$ solution

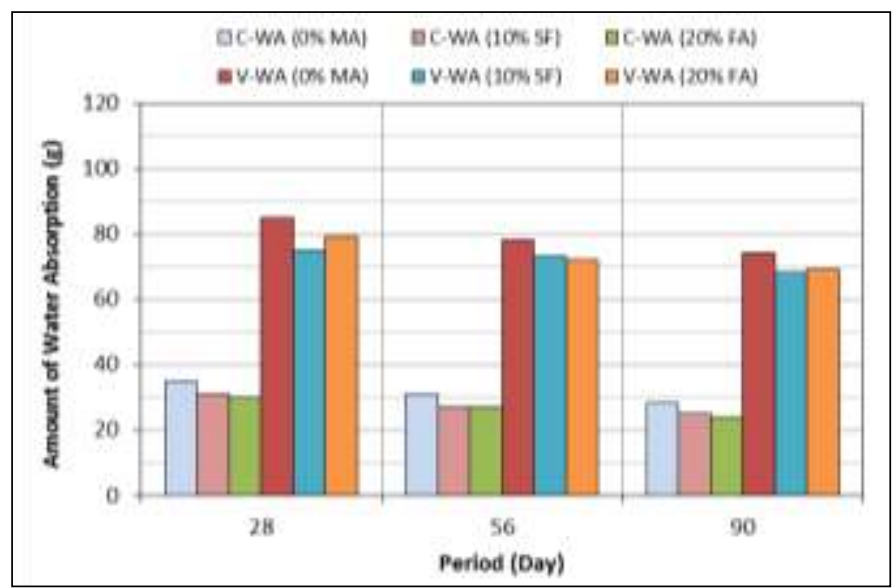

Figure 14. Water absorption amount of samples kept in $5 \% \mathrm{MgCl}_{2}$ solution 


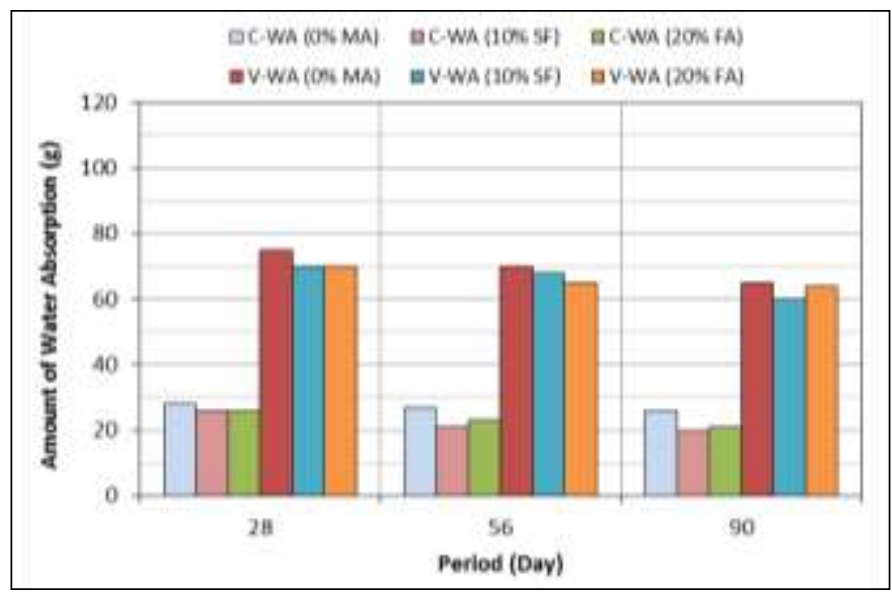

Figure 15. Water absorption amount of samples kept in $1.75 \% \mathrm{MgCl}_{2}+1.75 \%$ $\mathrm{NaCl}$ solutions

As shown in the figures; capillary and volumetric water absorption rates of concrete samples without mineral additives are the highest. The samples with $20 \% \mathrm{FA}$ and $10 \% \mathrm{SF}$ additive followed them, respectively. In concrete samples without mineral additives, there is more water absorption than concrete samples with SF. Also; in concrete samples, there are not so many difference of $\mathrm{NaCl}$ and $1.75 \% \mathrm{MgCl}_{2}+1.75 \%$ $\mathrm{NaCl}$ solutions than samples kept in standard curing waters. That is; $3.5 \%$ and $5 \% \mathrm{NaCl}$ and mixture solutions did not affect so much the concrete. However; samples in $\mathrm{MgCl}_{2}$ solution absorb so much water because magnesium chloride enters into the concrete and raises the spaces more. In this case; $20 \%$ FA and 10\% SF showed better attitude than samples without mineral additives.

\section{Results}

When the experimental results obtained from test studies for 28,56 and 90 days were compared with together; the following consideration may be said;

1. The compressive strength of the samples allowed in the standard curing showed increasing within 120 days free from mineral additives. While the highest strength value was obtained from samples with $20 \%$ FA, the samples with $10 \%$ $\mathrm{SF}$ and without mineral additive was followed them, respectively.

2. It was observed that for both solution rates, the $\mathrm{NaCl}$ salt and mixture solution had not significant effect on compressive strength and water absorption of concrete, especially in short time.

3. But, $\mathrm{MgCl}_{2}$ salt showed more effects than $\mathrm{NaCl}$ in terms of compressive strength and water absorption for both solution rates. Because; Na+ and $\mathrm{K}+$ ions are kept by silica surface in the cement. In gel composition; this gel mixes in the case of hydrate by increasing the rate of alkali and starts to separate. Magnesium chloride $\left(\mathrm{MgCI}_{2}\right)$ causes calcium chloride formation $\left(\mathrm{CaCI}_{2}\right)$. With increasing the rate of calcium chloride in the concrete surface; it provides the formation of calcium chloric aluminate; so this material is so dangerous for the concrete surfaces.

$$
\mathrm{MgCI}_{2}+\mathrm{Ca}(\mathrm{OH})_{2} \rightarrow \mathrm{Mg}(\mathrm{OH})_{2}+\mathrm{CaCI}_{2}
$$

When the $\mathrm{CaCI}_{2}$ is in a little water as solution; it accelerates increasing of strength by accelerating set of concrete. In addition, it can be harmful a certain degree for cement due to $\mathrm{CaCI}_{2}$ condensation.

4. $\mathrm{MgCl}_{2}$ get decreased the compressive strength increasing acceleration of samples as the time passes and this explains that $\mathrm{MgCl}_{2}$ is so dangerous for the concrete.

5. When the evaluation in terms of mechanical strength was made; it can be said that Fly Ash and silica fume increase the strength till a certain point. Using of Fly Ash had a positive effect on the strength of concrete against $\mathrm{MgCl}_{2}$. However; other physical and chemical effects of the concrete with the observation of long-term performance would be useful.

6. In sea structures and wet places in which alkaliaggregate reaction develops fast; using of perlite aggregate concrete should be increased.

7. The loss of strength in samples without mineral additives for 90 days was more. This situation showed that; the concrete samples with mineral additives have better performance in $\mathrm{MgCl}_{2}$ medium.

8. In concrete samples with Silica Fume and Fly Ash; these provides durability and resistance against to salts that affect to durability negatively such as $\mathrm{MgCl}_{2}$ because those fill spaces in concrete.

\section{References}

[1] Ünal, O., Yurtcu. Ş., 2007. The use of ready-mixed concrete in reinforced concrete structures, Building Technology Electronic Journal 2007 (1) $51-64$

[2] Yıldız, K., 2012. Investigation of Reinforced concrete of pumice and zeolite in terms of the availability of roads and $\mathrm{NaCl}$ effects/Journal of Advanced Technology Sciences Volume 1, No 1, 69-79.

[3] Ulusu, İ., 2007. Investigation of high-strength lightweight concrete reproducibility by using raw perlitea, Erzurum.

[4] Gökçe, H. S., Şimşek, O., Durmuş, G., Demir, İ., 2010. Alternative expanded perlite effect of the use towards Crude perlite aggregated lightweight concrete properties. Polytechnics Magazine Volume: 13 Issue: 2 p. 55-63, 2010.

[5] Erdoğan, T. Y., 2003. Concrete, METU Development Foundation broadcasting and Communication Co. Ltd, 513604 page.

[6] Yiğiter, H., Aydın, S., Yazıcı, H., 2004. Investigation of some physical, mechanical and durability properties of concretes with C type Fly Ash.

[7] Anonymous, 2004. TS 1114 EN 13055-1, Light Aggregates, Chapter 1, Concrete, For Use in Grouting and Watering TSE, Ankara.

[8] Anonymous, 2000. TS 500, Requirements for design and construction of reinforced concrete structures. Turkish Standards Institute Ankara.

[9] Anonymous, 1998. TS 3114 ISO 4012, Concrete-Determination of compressive strength of test specimens. Turkish Standards Institute Ankara.

[10] Anonymous, 1996. ASTM C 31, Making and Curing Concrete Test Specimens in the Field, Annual Book of ASTM Standards.

[11] Anonymous, 2002. ASTM C 39, Test Method for Compressive Strength of Cylindrical Concrete, Annual Book of ASTM Standards.

[12] Anonymous, 2002. ASTM C 567, Test Method for Density of Structural lightweight Concrete, Annual Book of ASTM Standards. 